\section{PERLINDUNGAN KONSUMEN TERHADAP PEREDARAN MAKANAN KEDALUWARSA DI KOTA MANADO ${ }^{1}$ \\ Oleh: Ribka Anasthasia Eva Karamoy ${ }^{2}$ Merry E. Kalalo ${ }^{3}$ \\ Mercy M. M. Setlight ${ }^{4}$}

\begin{abstract}
ABSTRAK
Penelitian di lakukan dengan melakukan metode penelitian hukum normatif. Jenis data yang digunakan dalam penelitian ini adalah data primer dan data sekunder. Data yang telah diperoleh baik dari bahan hukum primer, bahan hukum sekunder dan bahan hukum tersier selanjutnya dianalisa dengan landasan teori dengan menggunakan analisis data kualitatif. Hasil penelitian menunjukkan bahwa dalam perlindungan konsumen perlu adanya penyuluhan secara rutin kepada masyarakat yang dilakukan oleh pihak yang terkait maka diharapkan kepada masyarakat agar lebih berhati-hati dan cerdas dalam membeli dan mengkonsumsi produk-produk makanan kemasan yang dibeli. Dan dalam pengawasan yang dilakukan oleh Dinas Kesehatan, Dinas Perindustrian dan Perdagangan, BBPOM, YLKI, Pemerintah, Masyarakat, serta Pelaku Usaha/Sales harus lebih tegas dan melindungi masyarakat untuk menanggulangi peredaran produk - produk makanan kemasan kedaluwarsa.

Kata Kunci: Perlindungan Konsumen, Makanan Kedaluwarsa, Kota Manado
\end{abstract}

\section{PENDAHULUAN}

\section{A. Latar Belakang Masalah}

Di Indonesia sudah ada upaya yang dilakukan oleh pemerintah dalam melindungi konsumen yaitu adanya Undang - Undang No. 8 Tahun 1999 tentang Perlindungan Konsumen . Dalam Pasal 7 (b) Undang - Undang Perlindungan Konsumen disebutkan bahwa kewajiban pelaku usaha adalah memberikan informasi yang benar, jelas dan jujur mengenai kondisi dan jaminan barang dan/atau jasa serta memberi penjelasan penggunaan, perbaikan dan pemeliharaan. Begitu pula tercantum dalam Pasal 4 (a) dimana hak atas kenyamanan, keamanan, dan

\footnotetext{
${ }^{1}$ Artikel Tesis.

${ }^{2}$ Mahasiswa pada Pascasarjana Unsrat, NIM. 17202108007

${ }^{3}$ Fakultas Hukum Unsrat, Doktor IImu Hukum

${ }^{4}$ Fakultas Hukum Unsrat, Doktor IImu Hukum
}

keselamatan dalam mengkonsumsi barang dan/atau jasa serta Pasal 4 (c) hak atas informasi yang benar, jelas, dan jujur mengenai kondisi dan jaminan barang dan/atau jasa.

Undang - Undang No. 8 Tahun 1999 tentang Perlindungan Konsumen upaya dalam melindungi konsumen juga dengan berdirinya Yayasan Lembaga Konsumen Indonesia (YLKI) pada bulan Mei 1973, YLKI di berbagai provinsi memiliki nama sendiri-sendiri termasuk kota manado. Selain YLKI pemerintah juga membentuk suatu lembaga yakni Badan Pengawas Obat dan Makanan (BPOM). Berdasarkan Keputusan Presiden No. 103 Tahun 2001 Tentang Kedudukan, Tugas, Fungsi, Kewenangan, Susunan Organisasi, dan Tata Kerja Lembaga Pemerintah Non Departemen, merupakan badan yang bertugas di bidang pengawasan obat dan makanan yakni mengawasi keamanan, mutu, dan gizi pangan yang beredar di dalam negeri. Kegiatan oleh Badan Pengawas Obat dan Makanan (BPOM) dalam melakukan uji sampel produk makanan yang beredar di masyarakat merupakan bentuk perlindungan terhadap konsumen agar hak konsumen untuk mendapatkan keamanan dan kenyamanan dalam mengonsumsi suatu produk makanan terpenuhi.

Perlindungan konsumen adalah bagian dari hukum yang memuat asas - asas atau kaidah kaidah yang bersifat mengatur dan juga mengandung sifat yang melindungi kepentingan konsumen. Adapun hukum konsumen diartikan sebagai keseluruhan asas - asas dan kaidah kaidah hukum yang mengatur hubungan dan masalah antara berbagai pihak satu sama lain yang berkaitan dengan barang atau jasa konsumen dalam pergaulan hidup. ${ }^{5}$ Dalam Pasal 1 angka (1) Undang - Undang No. 8 Tahun 1999 tentang Perlindungan Konsumen, disebutkan bahwa "Perlindungan Konsumen adalah segala upaya yang menjamin adanya kepastian hukum untuk memberi perlindungan kepada konsumen". Oleh karena itu, berbicara mengenai perlindungan konsumen berarti mempersoalkan mengenai jaminan ataupun kepastian mengenai terpenuhinya hak - hak konsumen. Sebagaimana yang diketahui bahwa dengan adanya globalisasi dan perkembangan - perkembangan

\footnotetext{
${ }^{5}$ A Z. Nasution. 1995. Konsumen dan Hukum : Tinjauan Sosial Ekonomi dan Hukum Pada Perlindungan Konsumen. Jakarta : Pustaka Sinar Harapan. 64 - 65.
} 
perekonomian yang terjadi secara pesat di dalam era perekonomian modern ini telah menghasilkan berbagai jenis dan variasi dari barang dan/atau jasa yang dapat dikonsumsi oleh masyarakat.

Pengawasan pangan merupakan kegiatan pengaturan wajib oleh pemerintah pusat maupun daerah untuk memberikan perlindungan kepada konsumen dan menjamin bahwa semua produk pangan sejak produksi, penanganan, penyimpanan, pengolahan dan distribusi adalah aman, layak dan sesuai untuk dikonsumsi manusia, memenuhi persyaratan keamanan dan mutu pangan, dan telah diberi label dengan jujur dan tepat sesuai hukum yang berlaku. Dan juga kewajiban untuk menjamin keamanan suatu produk makanan agar tidak menimbulkan kerugian bagi konsumen yang dibebankan kepada produsen dan pelaku usaha, karena pihak produsen dan pelaku usahalah yang mengetahui komposisi dan masalah masalah yang menyangkut keamanan suatu produk makanan tertentu dan keselamatan di dalam mengkonsumsi produk makanan tersebut. Kerugian - kerugian yang diderita oleh konsumen merupakan akibat kurangnya tanggung jawab pelaku usaha terhadap konsumen.

Yang diketahui bahwa peredaran produk makanan kedaluwarsa ini tidak hanya terjadi di toko - toko kecil. Akan tetapi juga banyak terjadi di pasar modern, swalayan, dan supermarket. Dalam penelitian ini produk makanan kedaluwarsa yang dimaksud seperti produk makanan kemasan berupa roti, makanan ringan, dan biskuit. Di Indonesia terlebih di wilayah kota manado sudah banyak minimarket, midimarket, supermarket dan hypermarket yang menjual segala kebutuhan masyarakat sehari - hari seperti makanan, minuman, dan barang kebutuhan rumah tangga, dan lain - lain. Contohnya minimarket yang ada di kota manado seperti gerai alfamart dengan jumlah gerai sebanyak 74 (tujuh puluh empat) gerai di kota manado ${ }^{6}$ dan gerai indomaret di kota manado sebanyak 93 (sembilan puluh tiga) gerai ${ }^{7}$ dan akan bertambah di daerah kota manado dan

\footnotetext{
${ }^{6}$ Arthur. Kepala Gerai Alfamart cabang Sario. Wawancara Pribadi. Kotamadya Manado. Jumat, 29 Maret 2019. pukul 18:39 wita.

7 Novry. Management Development PT. Indomarco Prismatama Cabang Manado. Wawancara Pribadi. Kotamadya Manado. Kamis, 11 April 2019. pukul 13:16 wita.
}

sekitarnya, sedangkan midimarket seperti gerai alfamidi hanya berjumlah 35 (tiga puluh lima) gerai dan akan bertambah gerai alfamidi di daerah kota manado dan sekitarnya ${ }^{8}$, dan supermarket seperti fiesta supermarket, golden pasar swalayan, freshmart, giant ekstra kairagi, dan multimart modern, dan juga hypermarket seperti mantos (Manado Town Square) yang terdapat hypermart, megamall manado terdapat toko gelael, dan star square manado yang terdapat toko carrefour. Dan tidak dipungkiri bawah ada beberapa minimarket, midimarket, supermarket yang masih terdapat produk makanan kemasan yang sudah kedaluwarsa. Contohnya pada tahun 2015 menjelang hari raya idul fitri pihak tim BPOM Kota Manado dan pihak - pihak terkait mendapati beberapa supermarket di kota manado yang masih mengedarkan produk makanan kemasan yang sudah kedaluwarsa kurang lebih 2 hari pada etalase - etalase pada supermarket tersebut dan dalam, adapun juga pada tahun 2018 Dinas Kesehatan Kota Manado beserta tim BPOM dan pihak - pihak terkait melakukan sidak di supermarket dan minimarket dan masih ada ditemukan produk makanan kemasan yang sudah kedaluwarsa seperti kue - kue kering dalam kemasan beserta roti - roti yang masa expirenya sudah melewati 1 (satu) hari dan sudah tidak layak dikonsumsi. Pada kedudukan konsumen yang sangat awam terhadap barang barang yang dikonsumsinya dan adanya kesulitan untuk meneliti sebelumnya mengenai keamanan dan keselamatan di dalam mengkonsumsi barang tersebut.

Beredarnya produk makanan kemasan yang sudah kedaluwarsa sangatlah merugikan konsumen dan dapat membahayakan bagi kesehatan manusia. Akan tetapi, kerugiannya berlaku bagi semua orang (perorangan atau badan usaha) yang mengkonsumsi barang dan/atau jasa. Dengan posisi konsumen yang lemah ini, produsen atau pelaku usaha akan dengan mudah memasarkan barang dan/atau jasa tanpa memperhatikan hak - hak konsumen.

Mengenai perlindungan konsumen sama halnya dengan membicarakan tanggung jawab pelaku usaha/tanggung jawab produk (product liability), karena pada dasarnya tanggung jawab

\footnotetext{
${ }^{8}$ Risky. Kepala Toko Alfamidi cabang Kleak. Wawancara Pribadi. Kotamadya Manado. Senin, 04 Maret 2019. pukul 18:37 wita.
} 
produsen dimaksudkan untuk memberikan perlindungan kepada konsumen. Agnes M. Toar mengartikan tanggung jawab produk sebagai tanggungjawab para produsen untuk produk yang dibawanya ke dalam peredaran, yang menimbulkan atau menyebabkan kerugian karena cacat yang melekat pada produk tersebut. ${ }^{9}$

\section{B. Rumusan Masalah}

1. Bagaimana perlindungan konsumen dan pengawasan terhadap peredaran produk makanan kemasan kedaluwarsa di kota manado?

2. Bagaimana pertanggungjawaban pelaku usaha dalam peredaran produk makanan kemasan di kota manado?

\section{Tujuan Penelitian}

1. Untuk mengkaji dan menganalisa perlindungan konsumen dan pengawasan terhadap peredaran produk makanan kemasan kedaluwarsa di kota manado.

2. Untuk mengkaji dan menganalisa pertanggungjawaban pelaku usaha dalam peredaran produk makanan kemasan di kota manado.

\section{METODE PENELITIAN}

\section{A. Metode Penelitian}

Metode adalah cara yang tepat untuk melakukan suatu penelitian dengan menggunakan pikiran secara seksama untuk mncapai tujuan. Sedangkan penelitian adalah suatu kegiatan untuk mencari, mencatat, memaparkan dan menganalisis suatu yang diteliti sampai menyusun laporan. ${ }^{10}$

Penelitian hukum terbagi dua (2), yaitu penelitian hukum normatif dan penelitian hukum empiris. Penelitian hukum normatif merupakan penelitian hukum yang dilakukan dengan cara meneliti pustaka atau data sekunder. ${ }^{11}$ Penelitian hukum normatif disebut juga penelitian hukum dokrinal ${ }^{12}$. Hukum dikonsepkan sebagai apa yang tertulis dalam peraturan perundang - undangan (law in books)

\footnotetext{
${ }^{9}$ AZ Nasution. 1999. Hukum Perlindungan Konsumen Suatu Pengantar. Jakarta : Daya Widya. 242.

${ }^{10}$ Chalid Narbuko dan Abu Achmadi. 1997. Metodologi Penelitian. Jakarta : Bumi Aksara. 1.

${ }^{11}$ Peter Mahmud Marzuki. 2010. Penelitian Hukum. Jakarta : Kencana. 35.

${ }^{12}$ Ibid. 36.
}

atau hukum dikonsepkan sebagai kaidah atau norma yang merupakan patokan berprilaku manusia yang dianggap pantas, dan Penelitian hukum empiris, yaitu suatu metode penelitian hukum yang berfungsi untuk melihat hukum dalam artian nyata dan menelitian bagaimana bekerjanya hukum di lingkungan masyarakat. Dikarenakan dalam penelitian ini meneliti orang dalam hubungan hidup di masyarakat, maka metode penelitian hukum empiris dapat dikatakan sebagai penelitian hukum sosiologis. Dapat dikatakan bahwa penelitian hukum yang diambil dari fakta - fakta yang ada di dalam suatu masyarakat, badan hukum atau badan pemerintah.

Penelitian ini, jenis metode penelitian yang digunakan yaitu penelitian hukum normatif.

\section{B. Jenis Data}

Jenis data terdapat 2 (dua) jenis data yaitu pertama data primer adalah data yang diperoleh secara langsung dari sumber aslinya yang berupa wawancara, jajak pendapat dari individu atau kelompok (orang) maupun hasil observasi dari suatu obyek, kejadian atau hasil pengujian (benda). ${ }^{13}$ Data primer adalah data yang diperoleh langsung dari narasumber atau responden yaitu Dinas Kesehatan (Dinkes) Kota Manado, Perindustrian dan Perdagangan (Disperindag) Kota Manado, Badan Pengawas Obat dan Makanan (BPOM) Kota Manado, Yayasan Lembaga Konsumen Indonesia (YLKI) Kota Manado, Minimarket, Midimarket, dan Supermarket di Kota Manado. Data sekunder adalah data yang diperoleh melalui penelitian kepustakaan serta dokumentasi. Dokumentasi yang dimaksudkan dalam penelitian ini adalah data mengenai perlindungan konsumen terhadap peredaran produk makanan kemasan kedaluwarsa di kota Manado.

\section{Sumber Data}

Sumber data dalam penelitian adalah subyek dari mana data dapat diperoleh. ${ }^{14}$ Menurut Arikunto sumber data adalah subjek dari mana suatu data dapat diperoleh. Sumber data terbagi

\footnotetext{
${ }^{13}$ Amiruddin, dan H.Zainal Asikin. 2016. Pengantar Metode Penelitian Hukum. Edisi Revisi. Cet. 9. Jakarta : Rajawali Pers. 31.

${ }^{14}$ Suharsimi Arikunto. 2010. Preosedur Penelitian Suatu Pendekatan Praktik. Jakarta : PT Rineka Cipta. 129.
} 
dua (2) jenis yaitu sumber data primer, ${ }^{15}$ dan sumber data sekunder. ${ }^{16}$ Penelitian ini dalam data sekunder berupa studi kepustakaan, meliputi peraturan perundang - undangan, buku - buku, situs internet, media massa, dan kamus serta data yang terdiri atas:

1. Bahan Hukum Primer (primary source)

2. Bahan Hukum Sekunder (Secondary Source)

3. Bahan Hukum Tersier (Tertiary Source

\section{Lokasi Penelitian}

Lokasi penelitian adalah tempat dimana penelitian dilakukan. Lokasi penelitian berarti objek dan tujuan sudah ditetapkan sehingga mempermudah penulis dalam melakukan penelitian. Dalam Penelitian ini penulis memilih lokasi penelitian yaitu di Kota Manado.

\section{E. Teknik Pengumpulan Data}

Teknik pengumpulan data dalam penelitian ini dilakukan dengan cara kepustakaan (studi dokumen) dengan mengumpulkan bahan hukum dengan penelusuran dokumen yang berupa peraturan perundang - undangan, literature, karya ilmiah, jurnal hukum, maupun artikel yang berkaitan dengan penelitian, serta dengan cara wawancara pada narasumber yang berkaitan dengan penelitian.

\section{F. Analisis Data}

Data yang telah diperoleh baik dari bahan hukum primer, bahan hukum sekunder dan bahan hukum tersier selanjutnya dianalisa dengan landasan teori dengan menggunakan analisis data kualitatif.

\section{HASIL DAN PEMBAHASAN}

\section{A. Perlindungan Konsumen Dan Pengawasan Peredaran Produk Makanan Kemasan Kedaluwarsa}

1. Perlindungan Konsumen Dari Peredaran Produk Makanan Kemasan Kedaluwarsa

a. Penyuluhan Kepada Masyarakat

b. Meningkatkan Kesadaran Konsumen Dalam Mengkonsumsi Makanan

c. Mendorong Pelaku Usaha Untuk Menjaga Kualitas Produk Makanan Kemasan Yang Diperdagangkan

\footnotetext{
${ }^{15}$ Sumadi Suryabrata. 1987. Metode Penelitian. Jakarta : Rajawali. 93.

${ }^{16}$ Ibid. 94.
}

\section{d. Sanksi Bagi Pelaku Usaha Yang Melakukan Pelanggaran}

2. Pengawasan Peredaran Produk Makanan Kemasan Kedaluwarsa

a. Pengawasan Dinas Kesehatan (Dinkes)

b. Dinas Perindustrian dan Perdagangan (Disperindag)

c. Pengawasan Badan Pengawas Obat dan Makanan (BPOM)

d. Yayasan Lembaga Konsumen Indonesia (YLKI)

e. Pengawasan Pemerintah

f. Pengawasan Masyarakat

g. Pengawasan Pelaku Usaha dan Sales

\section{B. Pertanggungjawaban Pelaku Usaha Dalam Peredaran Produk Makanan Kemasan}

Bagi pelaku usaha yang mengimpor atau mengedarkan produk makanan kedaluwarsa termasuk produk makanan kemasan kedaluwarsa, maka dapat diberikan sanksi hukum berupa hukuman kurungan atau denda sebagaimana ditetapkan dalam Pasal 2 ayat (1) Undang - Undang Bahan Berbahaya Stb. 1949 No. 377, (Pasal 5 ayat (1) dan ayat (2)) Peraturan Menteri Kesehatan Republik Indonesia Nomor 180/MEN. KES/PER/ IV /1985). ${ }^{17}$

Pasal 19 dalam Undang - Undang No. 8 Tahun 1999 tentang Perlindungan Konsumen, penyebutkan bahwa pelaku usaha memiliki tanggungjawab sebagai berikut, yaitu :

1) Pelaku usaha bertanggungjawab memberikan ganti rugi atas kerusakan, pencemaran dan/atau kerugian konsumen akibat mengkonsumsi barang dan/atau jasa yang dihasilkan/diperdagangkan.

2) Ganti rugi sebagaimana dimaksud pada ayat (1) dapat berupa pengembalian uang atau penggantian barang dan/atau jasa yang sejenis/setara nilainya, atau perawatan kesehatan dan/atau pemberian santunan yang sesuai dengan ketentuan peraturan perundangundangan yang berlaku.

3) Pemberian ganti rugi dilaksanakan dalam tenggang waktu 7 (tujuh) hari setelah tanggal transaksi.

\footnotetext{
${ }^{17}$ Anak Agung Ayu Manik Pratiwiningrat, I Wayan Wiryawan, dan Dewa Gde Rudy. Tanggung Jawab Pelaku Usaha Terhadap Konsumen Yang Mengalami Kerugian Akibat Produk Makanan Kadaluarsa. Program Kekhususan Hukum Bisnis Fakultas Hukum Universitas Udayana. Jurnal.
} Hal 4 
4) Pemberian ganti rugi sebagaimana dimaksud pada ayat (1) dan ayat (2) tidak menghapuskan kemungkinan adanya tuntutan pidana berdasarkan pembuktian lebih lanjut mengenai adanya unsur kesalahan.

5) Ketentuan sebagaimana dimaksud pada ayat (1) dan ayat (2) tidak berlaku apabila pelaku usaha dapat membuktikan bahwa kesalahan tersebut merupakan kesalahan konsumen.

Pasal diatas telah menjelaskan bahwa pihak pelaku usaha memiliki tanggungjawab termasuk tanggungjawab atas adanya produk barang dan/atau jasa yang termasuk adanya produk makanan kemasan yang sudah kedaluwarsa. ${ }^{18}$ Dalam hal ini bisa dikatakan bahwa pihak pelaku usaha mempunyai tanggungjawab bila terjadi kerugian yang dialami oleh konsumen atas produk barang dan/atau jasa yang diperdagangkan.

Tanggungjawab pihak pelaku usaha yang mengedarkan produk makanan kedaluwarsa (sudah tidak layak dikonsumsi) termasuk produk makanan kemasan yang sudah kedaluwarsa berupa tanggungjawab pidana, tanggungjawab perdata, dan tanggungjawab administrasi.

1. Tanggungjawab Pidana

Undang - Undang No. 8 Tahun 1999 tentang Perlindungan Konsumen secara telah mengatur mengenai ketentuan pidana bagi pelaku usaha yang merugikan pihak konsumen, yaitu sebagai berikut: ${ }^{19}$

2. Tanggungjawab Perdata

Pasal 1365 Kitab Undang - Undang Hukum Perdata (KUHPer) telah mengantur tentang ganti rugi akibat perbuatan melawan hukum, yaitu : ${ }^{20}$

"Tiap perbuatan melanggar hukum, yang membawa kerugian kepada seorang lain, mewajibkan orang yang karena salahnya menerbitkan kerugian itu, mengganti kerugian tersebut". Terdapat unsur-unsur untuk menuntut ganti rugi dalam perbuatan melanggar hukum, yaitu $:^{21}$

\footnotetext{
18 Ibid. 5.

19 Jesica Gloria Grace Tambuwun. Peranan Hukum Perlindungan Konsumen Terhadap Peredaran Makanan Kadaluwarsa. Lex Privatum, Vol.II/No. 2/April/2014. 61

${ }^{20}$ R. Subekti dan R. Tjitosudibio, 1983, Kitab UndangUndang Hukum Perdata, Pradnya Paramita, Jakarta, hal.310.

${ }^{21}$ Ahmadi Miru, Op.cit., hal.74-87.
}

a. Adanya perbuatan melanggar hukum.

b. Adanya kerugian.

c. Adanya kausalitas antara perbuatan melanggar hukum dan kerugian.

d. Adanya kesalahan.

Perbuatan mengedarkan produk makanan kemasan kedaluwarsa oleh pelaku usaha adalah salah satu perbuatan melawan hukum yang mengakibatkan kerugian bagi pihak konsumen. Pasal 19 ayat (1) Undang - Undang No. 8 Tahun 1999 tentang Perlindungan Konsumen, disebutkan bahwa: "Pelaku usaha bertanggung jawab memberikan ganti rugi atas kerusakan, pencemaran dan/atau kerugian konsumen akibat mengkonsumsi barang dan/atau jasa yang dihasilkan atau diperdagangkan". Berdasarkan ayat tersebut maka dalam hal pemberian ganti rugi oleh pihak pelaku usaha dapat dilakukan setelah adanya putusan yang telah berkekuatan hukum tetap dan ganti rugi juga dapat berupa penggantian barang, pengembalian uang, perawatan kesehatan, dan pemberian santunan yang diberikan dalam tenggang waktu 7 (tujuh) hari setelah tanggal transaksi. Maka dalam hal ini dapat disimpulkan bahwa dalam tanggungjawab perdata dibebankan kepada pelaku usaha yang dapat berupa pemberian ganti rugi atas apa yang di derita oleh konsumen. dan jika pelaku usaha menolak/atau tidak memberikan tanggapan ataupun tidak mau memenuhi ganti rugi atas kerugian yang dialami konsumen, maka konsumen dapat melakukan tuntutan melalui Badan Penyelesaian Sengketa Konsumen (BPSK) atau mengajukan gugatan ke badan peradilan di tempat kedudukan konsumen.

3. Tanggungjawab Administrasi

Hukum administrasi berperan dalam penetapan pemberian suatu izin usaha yang merupakan suatu tibdakan administrasi berdirinya suatu perusahaan secara legalitas. Undang - Undang No. 23 Tahun 1992 tentang Kesehatan mempunyai ketentuan hukum administrasi yaitu pada Pasal 73 menyebutkan bahwa "Pemerintah melakukan pembinaan terhadap semua 
kegiatan yang berkaitan dengan penyelenggaraan upaya kesehatan", dan pada Pasal 76 juga menyebutkan bahwa "Pemerintah melakukan pengawasan terhadap semua kegiatan yang berkaitan dengan penyelenggaraan upaya kesehatan, baik yang dilakukan oleh pemerintah maupun masyarakat".

Berdasarkan kedua pasal tersebut sanksi administrsi ini tidak hanya ditujukan kepada konsumen itu sendiri, akan tetapi lebih ditujukan pada pengusaha sebagai produsen ataupun penyalur hasil produknya dalam hal ini penyalur produk makanan kemasan. Dalam sanksi administrasi berkaitan erat dengan hal perizinan yang diberikan oleh pemerintah kepada para pengusaha yang di dalamnya sebagai penyalur produk makanan kemasan. Dan jika didapati pelanggaran maka dari pihak pemerintah dapat mencabut izin dari perusahaan yang memproduksi produk makanan kemasan tersebut. Dalam hal pencabutan izin ini bertujuan untuk menghentikan proses produksi suatu produk makanan kemasan dari produsen/atau penyalur.

Tanggungjawab sanksi administrasi ini juga dapat dijatuhkan apabila telah melalui proses pemeriksaan di dalam pengadilan ataupun di luar pengadilan, dan apabila putusan itu berasal dari pengadilan, maka putusan tersebut telah mempunyai kekuatan hukum yang tetap, sehingga dapat dikatakan sudah ada kepastian hukum dalam penyelesaian permasalahan yang terjadi antara konsumen dan pelaku usaha.

Pertanggungjawaban administrasi ini bisa dijatuhkan oleh Badan Penyelesaian Sengketa Konsumen (BPSK) kepada pihak pelaku usaha yang melakukan pelanggaran, yaitu : "Tidak dilaksanakannya pemberian ganti rugi oleh pelaku usaha kepada konsumen, dalam bentuk pengembalian uang atau penggantian barang dan/atau jasa sejenis, maupun perawatan kesehatan/ pemberian santunan atas kerugian yang diderita oleh konsumen". ${ }^{22}$

\section{PENUTUP}

\section{A. Kesimpulan}

1. Dalam perlindungan konsumen perlu adanya penyuluhan secara rutin kepada masyarakat yang dilakukan oleh pihak yang terkait maka diharapkan kepada masyarakat agar lebih berhati - hati dan cerdas dalam membeli dan mengkonsumsi produk - produk makanan kemasan yang dibeli. Dan dalam pengawasan yang dilakukan oleh Dinas Kesehatan, Dinas Perindustrian dan Perdagangan, BBPOM, YLKI, Pemerintah, Masyarakat, serta Pelaku Usaha/Sales harus lebih tegas dan melindungi masyarakat untuk menanggulangi peredaran produk produk makanan kemasan kedaluwarsa.

2. Dalam pertanggungjawab pihak pelaku usaha yang mengedarkan produk makanan kedaluwarsa (sudah tidak layak dikonsumsi) termasuk produk makanan kemasan yang sudah kedaluwarsa berupa tanggungjawab pidana, tanggungjawab perdata, dan tanggungjawab administrasi.

\section{B. Saran}

1. Bagi konsumen, diharapkan agar lebih berhati - hati dalam mengkonsumsi suatu produk makanan dengan memperhatikan batas waktu kedaluwarsa makanan tersebut dan bagi Pemerintah dan lembaga - lembaga perlindungan konsumen, haruslah lebih tegas lagi dalam memberikan sanksi terhadap pelaku usaha yang mengedarkan produk makanan kedaluwarsa termasuk produk makanan kemasan kedaluwarsa serta lebih meningkatkan lagi perlindungan dan pengawasannya terhadap peredaran produk makanan yang sudah tidak layak di konsumsi (kedaluwarsa) oleh konsumen.

2. Pertanggungjawaban pelaku usaha harus lebih tegas lagi bagi para pelaku yang masih mengedarkan produk makanan kemasan yang sudah kedaluwarsa agar ada efek jerah bagi pelaku usaha itu sendiri agar tidak melakukan lagi hal tersebut.

\section{DAFTAR PUSTAKA}

AZ.Nasution. 1995. Konsumen dan Hukum : Tinjauan Sosial Ekonomi dan Hukum Pada Perlindungan Konsumen. Jakarta : Pustaka Sinar Harapan.

Arthur. Kepala Gerai Alfamart cabang Sario. Wawancara Pribadi. Kotamadya

\footnotetext{
${ }^{22}$ Gunawan Widjaja dan Ahmad Yani, Op.cit., hal.84.
} 
Manado. Jumat, 29 Maret 2019. pukul 18:39 wita.

Novry. Management Development PT. Indomarco Prismatama Cabang Manado. Wawancara Pribadi. Kotamadya Manado. Kamis, 11 April 2019. pukul 13:16 wita.

Risky. Kepala Toko Alfamidi cabang Kleak. Wawancara Pribadi. Kotamadya Manado. Senin, 04 Maret 2019. pukul 18:37 wita.

AZ Nasution. 1999. Hukum Perlindungan Konsumen Suatu Pengantar. Jakarta : Daya Widya.

Chalid Narbuko dan Abu Achmadi. 1997. Metodologi Penelitian. Jakarta : Bumi Aksara.

Peter Mahmud Marzuki. 2010. Penelitian Hukum. Jakarta : Kencana.

Amiruddin, dan H.Zainal Asikin. 2016. Pengantar Metode Penelitian Hukum. Edisi Revisi. Cet. 9. Jakarta : Rajawali Pers.

Suharsimi Arikunto. 2010. Preosedur Penelitian Suatu Pendekatan Praktik. Jakarta : PT Rineka Cipta.

Sumadi Suryabrata. 1987. Metode Penelitian. Jakarta : Rajawali.

Anak Agung Ayu Manik Pratiwiningrat, I Wayan Wiryawan, dan Dewa Gde Rudy. Tanggung Jawab Pelaku Usaha Terhadap Konsumen Yang Mengalami Kerugian Akibat Produk Makanan Kadaluarsa. Program Kekhususan Hukum Bisnis Fakultas Hukum Universitas Udayana. Jurnal.

Jesica Gloria Grace Tambuwun. Peranan Hukum Perlindungan Konsumen Terhadap Peredaran Makanan Kadaluwarsa. Lex Privatum, Vol.II/No. 2/April/2014.

R. Subekti dan R. Tjitosudibio, 1983, Kitab Undang-Undang Hukum Perdata, Pradnya Paramita, Jakarta. 